\title{
Tanító szakos hallgatók véleménye a magyarországi környezeti problémákról
}

\author{
Kulman Katalin \\ Eötvös Loránd Tudományegyetem Tanitó- és Óvóképzö Kar Matematika Tanszék
}

\begin{abstract}
Absztrakt
Az általános iskolában tanító pedagógusok munkájának fontos része a környezeti nevelés és a fenntarthatóságra nevelés. Ezek keretében készítik fel tanítványaikat a mindennapi életben használható tudásra, a környezeti problémák megértésére és megoldási lehetőségük ismeretére. A környezeti neveléshez tartozik az egyén felelősségérzésének kialakítása, és a rendszerszemlélet elsajátíttatása - például, hogy bizonyos gazdasági, társadalmi és környezeti jelenségek összefüggnek egymással. A kutatásban tanító szakos hallgatók véleményét mértem fel, hogy Magyarországon milyen gazdasági tevékenységek okozzák a legtöbb környezeti problémát. Külön kiemelve vizsgáltam véleményüket a levegőbe kerülő szén-dioxid és az üvegházhatású gázok okozta problémákról. Kutatásom kitért arra is, milyen forrásokból származnak a témával kapcsolatos ismereteik, illetve gazdasági eredményesség szempontjából megérheti-e az ipari és/vagy a bányászati környezetrombolás egy gazdálkodó szervezetnek. A kutatást kérdőíves formában valósítottam meg, a válaszok értékelése SPSS program segítségével történt.
\end{abstract}

Kulcsszavak: környezeti problémák, gazdasági tevékenység, tanítóképzés

\section{Bevezetés}

Napjaink egyik kulcstémája a környezetszennyezés, a környezeti problémák súlyosbodása. Ezekkel a problémákkal találkozhatunk a televíziós csatornák híreiben, a reklámok figyelemfelkeltő plakátjain és az internetes forrásokban egyaránt. E tájékoztató jellegű beszámolók nemcsak a felnőttek érdeklődését kelthetik fel, hanem már a fiatalabb korosztályét is. A mondanivaló megértéséhez azonban szükség van a témában való tájékozottságra, amely több tényezőtől is függ. Az egyik ilyen tényező az iskolapadban szerezhető tudás megléte. Ennek alapján a környezeti problémákról kialakított egyéni vélemények vizsgálata a tanító- és tanárképzésben résztvevőknél kulcsfontosságú, hiszen ők lesznek a következő generációk pedagógusai, akik a közoktatás keretein belül közvetítik tanítványaik számára a környezeti tartalmakat. Az ismeretátadás mellett saját hozzáállásuk, környezettudatos magatartásuk is mintaként szolgál a diákok számára. Alapvető, hogy a pedagógusi minta, amelyet követni tudnak a gyermekek, példaértékű legyen. 
A különböző természettudományos tantárgyak - jelen esetben a biológia, a kémia, a fizika és a földrajz - mindegyike foglalkozik valamilyen módon a gazdasági tevékenységek környezetet érő hatásaival és azok következményeivel, ugyanakkor jellegüknél fogva a földrajz tárgyhoz szorosabban kötődnek a bányászati és az ipari tevékenységek, valamint az általuk okozott környezeti problémák. A bányászat és az egyes iparágazatok kialakulása, ezeknek egy ország gazdaságában vagy a nemzetközi piacokon betöltött szerepük, eredményeik, hasznosságuk mind-mind a földrajzóra témái.

Alsó tagozaton ugyan nincs földrajz tantárgy, ennek ellenére adódhatnak olyan lehetőségek, föleg a környezetismeret-óra keretein belül, hogy a kisiskolások az életkori sajátosságaiknak megfelelő mértékben a gazdasági tevékenységek által okozott környezeti gondokkal foglalkozzanak. A gazdasági tevékenységek bemutatására bárhol könnyedén találhatunk példákat, akár a közvetlen környezetünkben is. A természeti környezetet szinte mindenütt érik olyan hatások, néha katasztrófák, amelyeknek okozói a bányászat és az ipari ágazatok. Az alsó tagozatos gyerekeknek is bemutatható a lokális környezet, annak problémái és megoldási lehetőségeik. Több helyen találkozhatunk Magyarország területén például elhagyatott külszíni fejtéssel, amely ma már tanösvényként segíti az alapfokú oktatást. Számtalan olyan példát lehetne még sorolni, ahol a környezeti nevelés közvetlen tapasztalatszerzéssel, megfigyelésekkel, vizsgálatok végzésével valósulhat meg. A tanulók számára a tevékenység-központú módszerek alkalmazása segítséget nyújthat a gazdasági tevékenységek környezetkárosító hatásainak felfedezésében és az ok-okozati összefüggések meglátásában, megértésében (Csenger, 2015).

Ahhoz, hogy a tanító kilépjen az iskola, a tanterem falain kívülre, és megismertesse a tanítványaival a környezetet, szüksége van belső indíttatásra, értékrendre, és emellett birtokában kell lennie a megfelelő ismereteknek, tudásanyagnak is.

\section{Környezeti problémák, a levegő szennyezése}

Földünk környezeti problémái közül az egyik legfontosabb a klímaváltozás. Ezt a tényt szakemberek kutatási eredményei bizonyítják. A levegő szennyezése, amely a klímaváltozást erősíti, alapvetően két forrásból származhat. Az egyik forrás a természetes légszennyezés, amelyet az emberiség közvetlenül nem befolyásol. Ilyenek lehetnek például a vulkánokból, erdőtüzekből, kozmikus eredetű anyagokból, valamint más forrásokból fakadó szennyező anyagok. Ezeket általában régóta zajló folyamatok eredményezik, amelyekhez a földi környezet és annak élővilága igazodik, és nem feltétlenül okoz károsodást (Pongrátz, 2012). A másik forrás az emberi tevékenységek által létrejövő, azaz antropogén eredetű légszennyezés. A szennyezőforrások közül példaként említhető az ipari termelés, a gépjárművek károsanyag-kibocsátása, a mezőgazdasági tevékenységek, a fosszilis energiahordozókat felhasználó erőművek, a bányászati tevékenységek és a hulladéklerakók (KSH, 2018). Az ilyen és ezekhez hasonló 
szennyezésekhez már kevésbé tudunk alkalmazkodni, hiszen lokális vagy globális szinten magas károsanyag-koncentrációk jelentkezhetnek (Bános, 2012).

A légszennyezők egyik típusa az aeroszolok, amelyek a levegő lebegő apró szilárd és cseppfolyós részecskéi. A másik csoportba a különböző gázok tartoznak, amelyek közül a tanulmány szempontjából kiemelendők az üvegházhatású gázok: vízgőz, szén-dioxid, metán, dinitrogén-oxid és ózon. Ezek a légkör olyan alkotóelemei, amelyek a rövid hullámhosszú napsugárzást szabadon átengedik, a földfelszínről visszaverődő hosszú hullámhosszú (infravörös) sugárzást elnyelik, ezzel az üvegházakkal megegyező müködési elvvel melegítve bolygónkat. Az üvegházhatás fontos a földi lét szempontjából, hiszen enélkül a bolygónkon az átlaghőmérséklet csak $-18{ }^{\circ} \mathrm{C}$ volna (Mészáros, 1993). Az üvegházhatás és a globális felmelegedés közötti összefüggést először Svante August Arrhenius jegyezte le 1896-ban. A kőszén égetésekor megnövekvő szén-dioxid koncentráció légköri következményeit írta le (Pongrácz \& Bartholy, 2010). A fosszilis tüzelőanyagok használata során gyárak, erőművek, közlekedési eszközök - nagy mennyiségü üvegházhatású gáz keletkezik. Az ipari forradalom kibontakozása óta a levegőben található mennyiségük jelentősen megnőtt (Kertész, 2001; Fry, 2008).

A pedagógusok számára a környezet szennyezésével, a globális felmelegedéssel kapcsolatos aktuális információk szerzése és ismerete elengedhetetlen ahhoz, hogy diákjaik számára megfelelő minőségű és mennyiségű új ismeretet adhassanak át. A mai világban már nemcsak a tankönyvekben leírtakra támaszkodhatnak a pedagógusok, hanem a különböző hírközlő papíralapú vagy online csatornákra is. A tanító- és tanárképzés során elsajátított alaptudást szükséges folyamatosan bővíteni, fejleszteni, hiszen a környezeti problémák is folyamatosan változnak. A diákok szempontjából is fontos az élethosszig tartó tanulásra, az önálló ismeretszerzésre való felkészítés (Radnóti, 2005). Ebből a nézőpontból is indokolt, hogy a pedagógusok az információszerzés lehetőségeit is megmutassák tanulóiknak, képesek legyenek a hírek és adatok sokaságában eligazodni, azok valóságtartalmát tanulmányozni, adott esetben kétségbe vonni. Az alsó tagozaton tanító pedagógusoknak is szükséges megtalálniuk azokat a környezeti tartalmakat, amelyek túlmutatnak a tankönyvekben leírtakon, amelyek az iskola falain kívül fedezhetők fel.

\section{A kutatás jellemzői, célja}

A kutatásban az ELTE Tanító- és Óvóképző Karának 41 hallgatója vett részt $(\mathrm{N}=41)$. Mindannyian végzős tanító szakosok voltak négy különböző műveltségi területről: Ember és társadalom (9 fö), Magyar nyelv és irodalom (10 fö), Természettudomány (13 fö) és Matematika (9 fö). A kutatás a 2019/2020-as tanév őszi szemeszterének második felében valósult meg önkitöltős kérdőíves formában. A feltett kérdéseket öt kérdéscsoportba soroltam. A tanulmányban a 2. kérdéscsoport kérdéseire adott válaszok elemzésére kerül sor. A kérdőívben többnyire zárt kérdések szerepeltek, emellett néhány kérdés 
esetében, amelyeknél kíváncsi voltam a hallgatók egyéni meglátására, nyílt kérdések is voltak (Boncz, 2015). A válaszok kiértékelése SPSS program segítségével történt. A vizsgálat kényelmi mintavétellel történt, melynek során nem játszottak szerepet reprezentativitási szempontok.

A kutatásban a hallgatók véleményére voltam kíváncsi azzal kapcsolatban, hogy szerintük Magyarországon mely gazdasági tevékenységek okozzák a legnagyobb környezeti problémát, továbbá melyek által kerül jelentős mennyiségű üvegházhatású gáz és szén-dioxid a levegőbe. Szintén érdekelt, hogy milyen információforrásból tájékozódnak a témát illetően. Azzal kapcsolatban is tartalmazott kérdést a kérdőív, hogy a megkérdezettek szerint gazdasági eredményesség szempontjából egy gazdálkodó szervezet számára profitábilis lehet-e az ipari és/vagy bányászati környezetrombolás-e.

\section{Eredmények}

A kérdőív 2. kérdéscsoportja a magyarországi környezeti problémákra, a levegő szennyezésére és az azokkal kapcsolatos ismeretek forrására fókuszált. A normalitáspróbák elvégzése után többváltozós nem parametrikus ismételt méréses teszteléssel (Friedman-teszt) vizsgáltam meg elsőként, hogy a válaszlehetőségek közötti eltérés szignifikáns-e vagy sem. Ezután megvizsgáltam azt, hogy a vizsgálatba bevont hallgatók szerint van-e összefüggés az információ forrása és a magyarországi környezeti problémák okozói, valamint a szén-dioxidot, illetve az üvegházhatású gázokat kibocsátó tevékenységek megítélése között (Field, 2017).

A vizsgált változók normalitástesztje valamennyi esetben szignifikáns eltérést mutat a normális eloszlástól, így nem feltételezve a normális eloszlást nem parametrikus próbával teszteltem a válaszlehetőségek középértékét, azaz a mediánt (Falus \& Ollé, 2000). (1. táblázat)

1. táblázat

A 2.3, 2.4., 2.5. és 2.7. kérdésre adott válaszok középértékei (medián) és normalitástesztjeinek eredményei

\begin{tabular}{|c|c|c|c|c|c|}
\hline Kérdés & Válaszlehetőség & Me & D & szf & Szig, \\
\hline \multirow{7}{*}{$\begin{array}{l}\text { 2.3. Vélemé- } \\
\text { nye szerint } \\
\text { Magyar- } \\
\text { országon } \\
\text { mi okozza } \\
\text { a legtöbb } \\
\text { környezeti } \\
\text { problémát? }\end{array}$} & Mezőgazdaság & 6 & 0,260 & 41 & $<0,001$ \\
\hline & Bányászat & 5 & 0,170 & 41 & 0,004 \\
\hline & Energiatermelés & 5 & 0,206 & 41 & $<0,001$ \\
\hline & Háztartások & 4 & 0,148 & 41 & 0,023 \\
\hline & Ipari termelés & 3 & 0,141 & 41 & 0,039 \\
\hline & Közlekedés & 2 & 0,190 & 41 & 0,001 \\
\hline & Hulladékkezelés & 2 & 0,246 & 41 & $<0,001$ \\
\hline
\end{tabular}




\begin{tabular}{|c|c|c|c|c|c|}
\hline \multirow{7}{*}{$\begin{array}{l}\text { 2.4. Vélemé- } \\
\text { nye szerint } \\
\text { Magyar- } \\
\text { országon } \\
\text { milyen tevé- } \\
\text { kenységből } \\
\text { származik } \\
\text { a levegőbe } \\
\text { kerülő szén- } \\
\text { dioxid döntő } \\
\text { része? }\end{array}$} & Mezőgazdaság, erdőgazdálkodás, halászat & 6 & 0,230 & 41 & $<0,001$ \\
\hline & Háztartások & 5 & 0,194 & 41 & $<0,001$ \\
\hline & $\begin{array}{l}\text { Vízellátás; szennyvíz gyűjtése, kezelése, hul- } \\
\text { ladékgazdálkodás, szennyeződésmentesítés }\end{array}$ & 5 & 0,186 & 41 & 0,001 \\
\hline & $\begin{array}{l}\text { Villamosenergia-, gáz-, gőzellátás, légkon- } \\
\text { dicionálás }\end{array}$ & 4 & 0,156 & 41 & 0,013 \\
\hline & Feldolgozóipar & 3 & 0,194 & 41 & $<0,001$ \\
\hline & Szállítás, közlekedés, raktározás & 3 & 0,171 & 41 & 0,004 \\
\hline & Kereskedelem, gépjárműjavítás & 3 & 0,169 & 41 & 0,005 \\
\hline \multirow{7}{*}{$\begin{array}{l}\text { 2.5. Vélemé- } \\
\text { nye szerint } \\
\text { Magyar- } \\
\text { országon } \\
\text { milyen tevé- } \\
\text { kenységek- } \\
\text { ből származ- } \\
\text { nak döntően } \\
\text { a levegőbe } \\
\text { kerülö üveg- } \\
\text { házhatású } \\
\text { gázok? }\end{array}$} & Mezőgazdaság, erdőgazdálkodás, halászat & 5,5 & 0,243 & 40 & $<0,001$ \\
\hline & Háztartások & 5,5 & 0,215 & 40 & $<0,001$ \\
\hline & $\begin{array}{l}\text { Vízellátás; szennyvíz gyűjtése, kezelése, hul- } \\
\text { ladékgazdálkodás, szennyeződésmentesítés }\end{array}$ & 5 & 0,184 & 40 & 0,002 \\
\hline & Kereskedelem, gépjárműjavítás & 4 & 0,188 & 40 & 0,001 \\
\hline & $\begin{array}{l}\text { Villamosenergia-, gáz-, gőzellátás, légkon- } \\
\text { dicionálás }\end{array}$ & 3 & 0,166 & 40 & 0,007 \\
\hline & Szállítás, közlekedés, raktározás & 3 & 0,183 & 40 & 0,002 \\
\hline & Feldolgozóipar & 2 & 0,238 & 40 & $<0,001$ \\
\hline \multirow{9}{*}{$\begin{array}{l}\text { 2.7. Honnan } \\
\text { származnak } \\
\text { az ipar és a } \\
\text { bányászat } \\
\text { környezeti } \\
\text { hatásaival } \\
\text { kapcsolatos } \\
\text { ismeretei? }\end{array}$} & Közösségi média (Facebook, Instagram stb.) & 3 & 0,195 & 40 & 0,001 \\
\hline & Újságok, folyóiratok (online és nyomtatott) & 3 & 0,174 & 40 & 0,004 \\
\hline & Iskola, tanárok & 3 & 0,217 & 40 & $<0,001$ \\
\hline & Televízió & 2 & 0,189 & 40 & 0,001 \\
\hline & YouTube & 2 & 0,269 & 39 & $<0,001$ \\
\hline & Reklámok, plakátok, poszterek & 2 & 0,234 & 40 & $<0,001$ \\
\hline & Szülők, testvérek, rokonok & 2 & 0,221 & 41 & $<0,001$ \\
\hline & Barátok, osztálytársak & 2 & 0,228 & 41 & $<0,001$ \\
\hline & egyéb & 1 & 0,431 & 21 & $<0,001$ \\
\hline
\end{tabular}

A 2.3-as kérdésben arra kértem a hallgatókat, hogy a felsorolt hét potenciális gazdasági tevékenységet rendezzék sorrendbe aszerint, hogy melyik okozza a legsúlyosabb környezeti problémát. A hallgatók a legsúlyosabbnak a közlekedést és a hulladékkezelést ítélték, melyeket az ipari termelés követett, majd a háztartások, ezután a bányászat és az energiatermelés következett holtversenyben, és legvégül a mezőgazdaság (1. ábra). Az elvégzett teszt alapján szignifikáns eltérést találtam az egyes környezeti problémákat okozó tevékenységek megítélése tekintetében $\left(\chi^{2}(6)=59,603 ; p<0,001\right)$. 


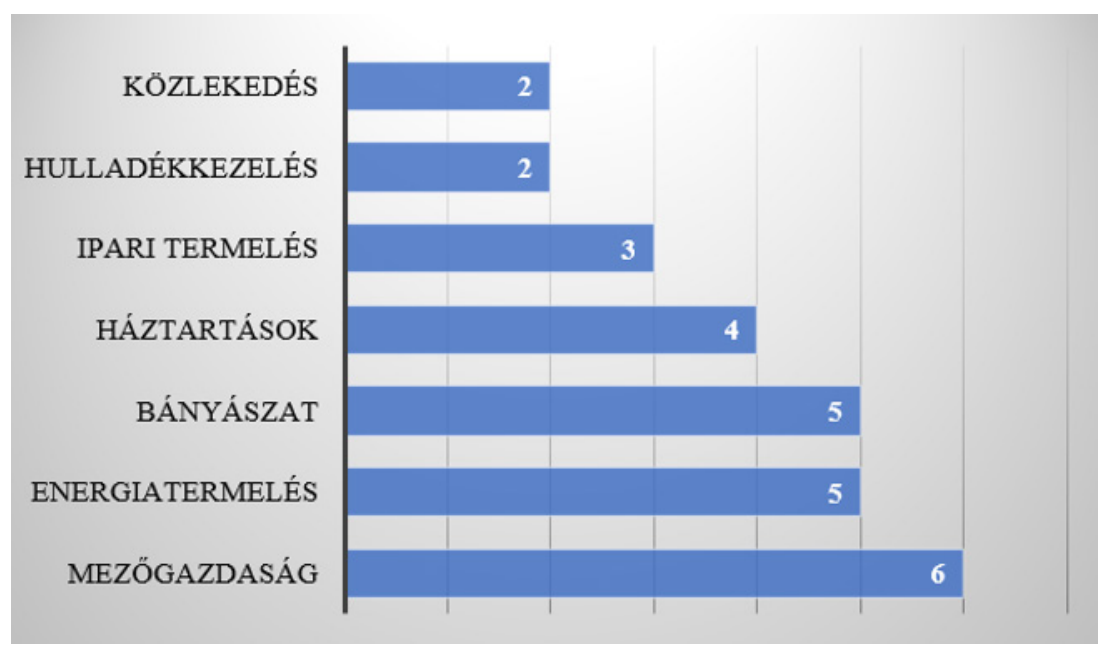

1. ábra

Véleménye szerint Magyarországon mi okozza a legtöbb környezeti problémát? kérdésre adott válaszok mediánjai ( $N=41$ fó)

Vizsgálatom harmadik kérdése arra vonatkozott, hogy a megkérdezettek megítélése szerint milyen tevékenységekből származik a levegőbe kerülő szén-dioxid döntő része. Ismét arra kértem a hallgatókat, hogy tegyék sorrendbe a felsorolt hét tevékenységet, alacsonyabb rangszámot rendelve a súlyosabbnak ítélthez. (2. ábra) A válaszadások alapján a levegőbe kerülő szén-dioxid nagy részét a megkérdezettek a feldolgozóiparnak, a szállításnak, közlekedésnek, a raktározásnak és a kereskedelemnek, valamint a gépjárműjavításnak tulajdonítják. Ezek után következik a villamosenergia-, gáz- és gőzellátás, légkondicionálás, majd holtversenyben a háztartások és a vízellátás, legvégül pedig a mezőgazdaság, erdőgazdálkodás, halászat. Az előbb bemutatott elemek közötti válaszadói különbségtétel szignifikáns, amit az elvégzett homogenitási teszt eredménye is igazol $\left(\chi^{2}(6)=26,394 ; p<0,001\right)$. 


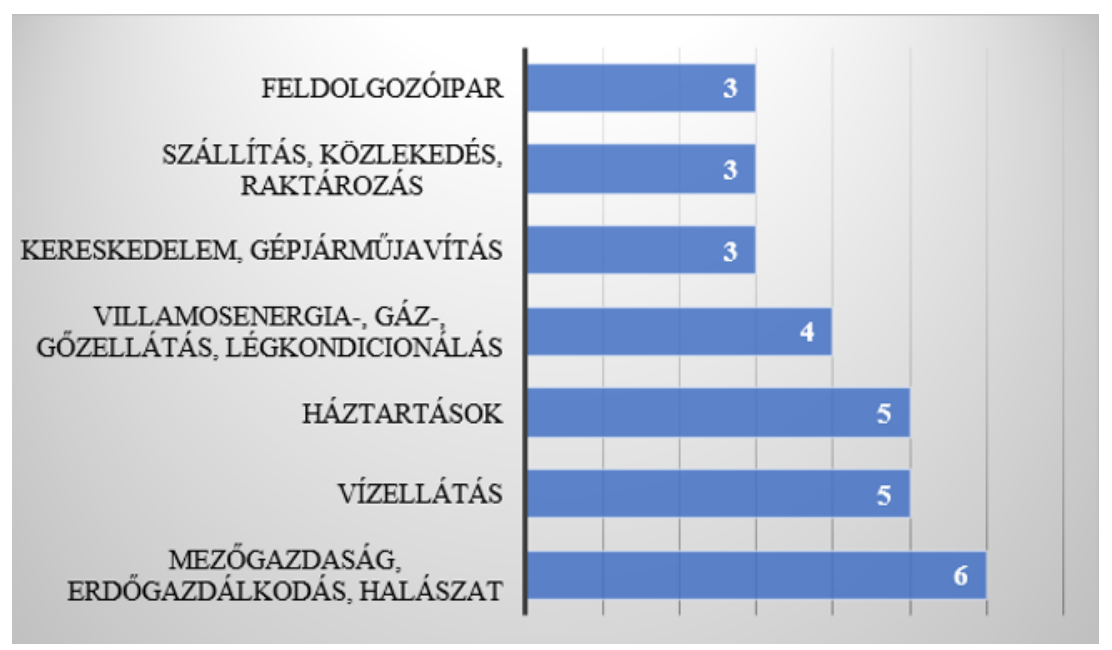

2. ábra

Véleménye szerint Magyarországon milyen tevékenységből származik a levegöbe kerülö szén-dioxid döntö része?

kérdésre adott válaszok mediánjai $(N=41$ fó)

Az üvegházhatású gázok kibocsátásáért leginkább ismét a feldolgozóipart tették felelőssé a megkérdezettek, azonban ezen kérdésre adott válaszok alapján a villamosenergia-, gáz- és gőzellátás, a légkondicionálás előre ugrott a második helyre a szállítás, közlekedés, raktározással holtversenyben, majd következett a kereskedelem, gépjárműjavítás, ezután a vízellátás és végül holtversenyben a mezőgazdaság, erdőgazdálkodás, halászat és a háztartások. (3. ábra) Az összehasonlításhoz elvégzett teszt alapján a tevékenységek megítélésének foka közötti eltérés szignifikáns $\left(\chi^{2}(6)=18,739 ; \mathrm{p}<0,001\right)$. 


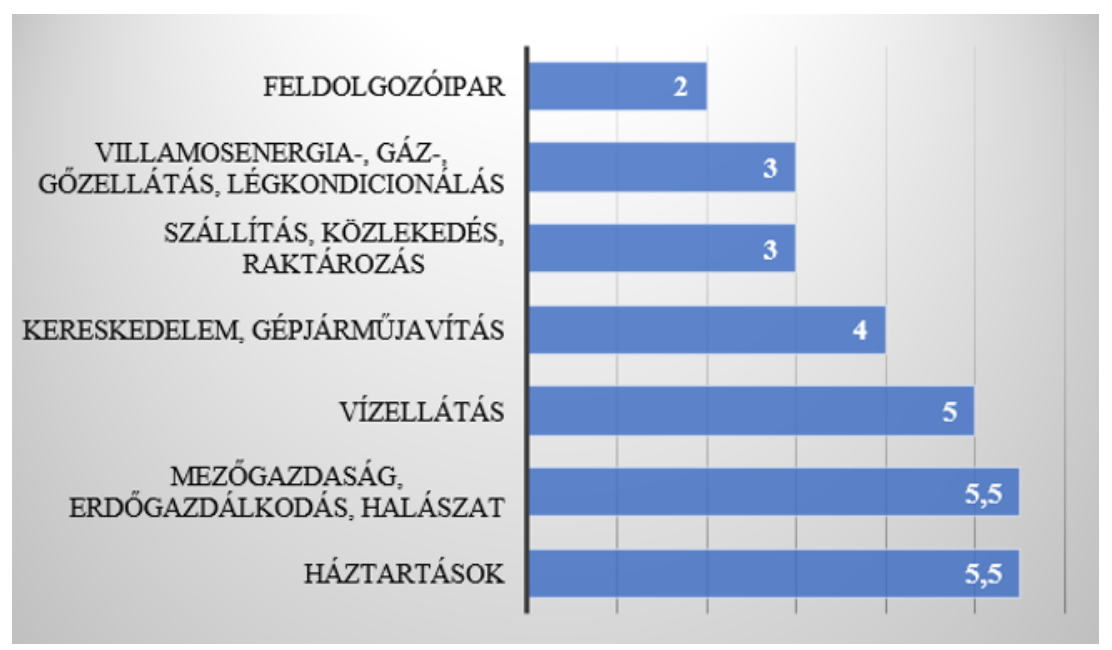

\section{3. ábra}

Véleménye szerint Magyarországon milyen tevékenységekből származnak döntöen a levegöbe kerülö üvegházhatású gázok?

kérdésre adott válaszok mediánjai $(N=41$ fó)

Az ipari és a bányászati tevékenységek környezeti hatásaival kapcsolatos ismeretek több forrásból is származhatnak. A kérdőív 2.7-es blokkjában arra voltam kíváncsi, hogy az általam felsorolt források milyen mértékủ információval szolgálnak a hallgatók számára. A nyolc nevesített információforrást a hallgatói válaszok alapján három csoportra lehet osztani: a legtöbb információt a témában, a vizsgálatba bevont hallgatók számára az iskola-tanárok, újságok-folyóiratok és a közösségi média adja. Közepes mennyiségü információforrásként szolgálnak számukra a barátok-osztálytársak, szülőktestvérek-rokonok, reklámok-plakátok-poszterek, a YouTube és a televízió. Legkisebb mértékben az egyéb forrást jelölték meg a hallgatók (4. ábra). Az ismeretek forrásainak az ismeret mennyisége tekintetében létrejövő sorrendje szignifikáns, amit az elvégzett teszt is igazol $\left(\chi^{2}(8)=40,910 ; N=41\right.$; $\mathrm{p}<0,001)$. 


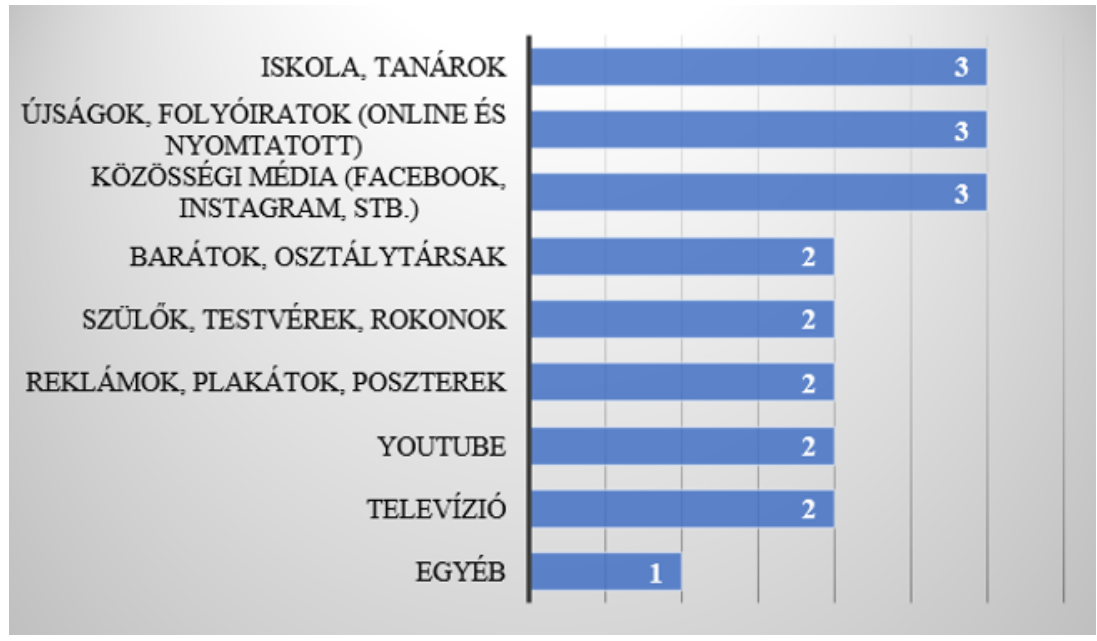

4. ábra

Honnan származnak az ipar és a bányászat környezeti hatásaival kapcsolatos ismeretei? kérdésre adott válaszok mediánjai ( $N=41$ fó)

A továbbiakban azt vizsgáltam meg, hogy van-e kapcsolat - és ha igen, akkor milyen irányú és milyen erős - az információszerzés forrása és a 2-es kérdéscsoport három kérdésére (2.3., 2.4. és 2.5.) adott válaszok között. Mivel nem volt feltételezhető a megkérdezettek válaszainak normális eloszlása (1. táblázat), továbbá valamennyi válasz ordinális mérési skálájú változó, ezért a Spearman-féle rangkorrelációs együtthatóval vizsgáltam a közöttük levő összefüggést (Field, 2017). Megjegyzendő, hogy a továbbiakban csupán a szignifikáns összefüggésekre térek ki (ezért sem szerepeltetem a „2.4. Véleménye szerint Magyarországon milyen tevékenységből származik a levegőbe kerülő szén-dioxid döntő része?" kérdésre adott válaszok összefüggéseit az információforrások fontosságát firtató kérdéssel, hiszen nem volt egyetlen kapcsolat sem szignifikáns) tekintettel a lehetséges változópárok nagy számára (189 darab). A könnyebb érthetőség érdekében a kapcsolat-szorossági mutató előjelét az ellentétére változtattam meg, mivel a kitöltés során a legsúlyosabb probléma az egyes számot kapta, hiszen a rangsor elején szerepelt.

Többnyire pozitív összefüggéseket találtam az információforrás fontossága és a környezeti problémák súlyosságának megítélése között: eszerint minél gyakrabban tájékozódik valaki a televízióból probléma forrásként annál gyakrabban jelöli a közlekedést; ugyanígy az iskolát, tanárokat mint információforrásokat előtérbe helyezők a mezőgazdaságot inkább problémának jelölték; a hulladékkezelést pedig azok jelölték problémának, akik a televízióból, újságokból, folyóiratokból vagy a reklámokból, plakátokból 
szerzik környezeti hatásokkal kapcsolatos ismereteik jelentős részét. A magyarországi környezeti problémák okozói esetében egyedül az „iskola, tanárok" mutatott negatív összefüggést az energiatermeléssel mint környezetre káros hatású tevékenységgel. Azaz minél inkább ezen forrásból merítette a megkérdezett az információit, annál kevésbé tartotta az energiatermelést a környezeti problémák forrásának. (2. táblázat)

\section{2. táblázat}

A Véleménye szerint Magyarországon mi okozza a legtöbb környezeti problémát? és a Honnan származnak az ipar és a bányászat környezeti hatásaival kapcsolatos ismeretei? kérdésekre adott hallgatói válaszok ( $N=41$ fó) szignifikáns kapcsolatban levő válaszai

\begin{tabular}{|c|c|c|c|c|}
\hline $\begin{array}{c}\text { 2.3. Véleménye szerint Ma- } \\
\text { gyarországon mi okozza a } \\
\text { legtöbb környezeti prob- } \\
\text { lémát? }\end{array}$ & $\begin{array}{c}\text { 2.7. Honnan származnak az } \\
\text { ipar és a bányászat környe- } \\
\text { zeti hatásaival kapcsolatos } \\
\text { ismeretei? }\end{array}$ & Minta & rho & Szig \\
\hline Közlekedés & Televízió & 40 & 0,489 & 0,001 \\
\hline Mezőgazdaság & Iskola, tanárok & 40 & 0,414 & 0,008 \\
\hline Energiatermelés & Iskola, tanárok & 40 & $-0,316$ & 0,047 \\
\hline Hulladékkezelés & Televízió & 40 & 0,357 & 0,024 \\
\hline Hulladékkezelés & $\begin{array}{c}\text { Újságok, folyóiratok (online } \\
\text { és nyomtatott) }\end{array}$ & 40 & 0,338 & 0,033 \\
\hline Hulladékkezelés & Reklámok, plakátok, posz- & 40 & 0,483 & 0,002 \\
\hline
\end{tabular}

A levegőbe kerülő üvegházhatású gázokért felelős tevékenységek közül kettő mutatott szignifikáns összefüggést az információ forrásával. Akik a YouTube-ról szerzik az információk nagyobb részét, azok a szállítás, közlekedés, raktározás esetében jobban érzik úgy, hogy ezen tevékenységek felelősek Magyarországon az üvegházhatású gázok levegőbe kerüléséért. Ezzel szemben az informális kapcsolatok megtestesítőinek (szülők, testvérek, rokonok, barátok, osztálytársak) fontossága mint információforrás kisebb valószínűséget rendel ahhoz, hogy valaki a kereskedelmet és a gépjármüjavítást tegye felelőssé az üvegházhatású gázok levegőbe kerüléséért. (3. táblázat) 
3. táblázat

A Véleménye szerint Magyarországon milyen tevékenységekböl származnak döntöen a levegöbe kerülö üvegházhatású gázok? és a Honnan származnak az ipar és a bányászat környezeti hatásaival kapcsolatos ismeretei? kérdésekre adott hallgatói válaszok $(N=41$ fö) szignifikáns kapcsolatban levö válaszai

\begin{tabular}{|c|c|c|c|c|}
\hline $\begin{array}{c}\text { 2.5. Véleménye szerint Ma- } \\
\text { gyarországon milyen tevé- } \\
\text { kenységekből származnak } \\
\text { döntően a levegőbe kerülö } \\
\text { üvegházhatású gázok? }\end{array}$ & $\begin{array}{c}\text { 2.7. Honnan származnak az } \\
\text { ipar és a bányászat környe- } \\
\text { zeti hatásaival kapcsolatos } \\
\text { ismeretei? }\end{array}$ & Minta & rho & Szig \\
\hline $\begin{array}{c}\text { Szállítás, közlekedés, } \\
\text { raktározás }\end{array}$ & YouTube & 38 & 0,349 & 0,032 \\
\hline $\begin{array}{c}\text { Kereskedelem, } \\
\text { gépjármüjavítás }\end{array}$ & Szülők, testvérek, rokonok & 40 & $-0,396$ & 0,011 \\
\hline $\begin{array}{c}\text { Kereskedelem, } \\
\text { gépjármüjavítás }\end{array}$ & Barátok, osztálytársak & 40 & $-0,410$ & 0,009 \\
\hline
\end{tabular}

Külön kérdés vonatkozott arra, hogy valaki mennyire érzi magát jól informáltnak az ipar és a bányászati tevékenységek környezeti hatásaival kapcsolatban. A válaszadók a kérdésben ötfokozatú Likert-skálán jelölhették be az informáltságuk mértékét. A módszer lényege, hogy a válaszadók két szélsőséges álláspont között kialakított skálán értékelnek, ahol az egyik végpont az abszolút ellenkezést, míg a másik a teljes egyetértést, azonosulást fejezi ki. A páratlan fokozat miatt ki lehet alakítani semleges álláspontot a köztes válaszok között (Zerényi, 2016). Az erre a kérdésre adott válaszok öszszefüggésben vannak szinte valamennyi információforrás fontosságával, de leginkább az iskola és tanárok, szülö-testvér-rokonok, barátok-osztálytársak és az újságok-folyóiratok mint információforrások mutatnak kapcsolatot az ezen kérdésre adott válaszokkal. (4. táblázat) Azaz minél jobban informáltnak érezte magát valaki, annál inkább jelölte meg információforrásként az általam nevesített csatornát. Ez azt jelenti, hogy az előbb felsorolt források fogják leginkább azt erősíteni, hogy valaki a saját tudását megbízhatónak tartja ebben a témában. 
4. táblázat

A Mennyire érzi jól informáltnak saját magát az ipar és a bányászat környezeti hatásaival kapcsolatban? és a Honnan származnak az ipar és a bányászat környezeti hatásaival kapcsolatos ismeretei? kérdésekre adott hallgatói válaszok $(N=41$ fó) szignifikáns kapcsolatai

\begin{tabular}{|l|c|c|c|}
\hline $\begin{array}{c}\text { 2.7. Honnan származnak az ipar és a bányászat } \\
\text { környezeti hatásaival kapcsolatos ismeretei? }\end{array}$ & Minta & rho & Szig \\
\hline Televízió & 40 & 0,380 & 0,016 \\
\hline YouTube & 39 & 0,285 & 0,079 \\
\hline Közösségi média (Facebook, Instagram stb.) & 40 & 0,339 & 0,033 \\
\hline Újságok, folyóiratok (online és nyomtatott) & 40 & 0,453 & 0,003 \\
\hline Reklámok, plakátok, poszterek & 40 & 0,274 & 0,087 \\
\hline Iskola, tanárok & 40 & 0,576 & $<0,001$ \\
\hline Szülők, testvérek, rokonok & 41 & 0,530 & $<0,001$ \\
\hline Barátok, osztálytársak & 41 & 0,496 & 0,001 \\
\hline
\end{tabular}

A Véleménye szerint gazdasági eredményesség szempontjából megérheti-e az ipari és/vagy bányászati környezetrombolás egy gazdálkodó szervezetnek? kérdéssel való egyetértés csökken, ha a forrás a közösségi média (Facebook, Instagram stb.). Ahogy látható, valamennyi információforrás jelentőséggel bír, csak más és más területen. Mindegyik információforrás eltérő véleményeket fog a megkérdezettekben generálni, azaz más és más tevékenységeket fognak károsnak ítélni Magyarország környezetével, levegőjének minőségével kapcsolatban.

\section{Összegzés}

A környezeti problémákról, ezen belül a légszennyezettségről is, a közoktatásban résztvevő pedagógusoknak tájékozottnak kell lenniük ahhoz, hogy tanulóiknak át tudják adni a tankönyvek tartalmán kívüli információkat. A kérdőíves vizsgálatban a tanítóképzésben lévő hallgatók vettek részt, így az is fontos szemponttá vált, hogy környezetükről, a majdani iskolájuk szükebb környezetét érő káros hatásokról is jól informáltak legyenek. A kutatás eredményei azt mutatják, nem mindegy, hogy milyen információforrásból érkeznek a környezettel kapcsolatos hírek. Ezt figyelembe véve a tanítóképzés során azokon a kurzusokon, amelyek környezeti kérdésekkel és tantárgy-pedagógiai elemekkel is foglalkoznak, célszerü lenne a hallgatókat arra ösztönözni, hogy a kérdést illetően több helyről szerezzék be az információikat, így átfogóbb képet kaphatnak a környezeti probléma kialakulásáról, az oko- 
zott károkról, a megoldási lehetőségekről és a hasonló esetek megelőzéséről. További kutatás tárgya lehet annak vizsgálata, hogy mely források mennyire megbízható információt nyújtanak.

Az aktuális helyzetek ismerete és a naprakész tudás megléte nélkülözhetetlen, ha valaki a pedagógus pályát választja. A Központi Statisztikai Hivatal 2018. évi adatai alapján a kutatásban felsorolt hazai nemzetgazdasági ágak és a háztartások adatait figyelembe véve elmondható, hogy a megkérdezettek informáltsága a levegőbe kerülő legnagyobb mennyiségű szén-dioxid és az üvegházhatású gázok forrásáról nem megfelelő. A statisztikai adatok alapján mindkét esetben a háztartások által kerül a legtöbb káros hatású gáz a légkörbe. A kutatás további folytatása lehet annak vizsgálata, vajon mi az oka annak, hogy a légszennyezés mértékét tekintve egyik esetben sem szerepeltek a háztartások első, második vagy harmadik helyen . A kutatás jelen állása szerint a megkérdezett tanító szakos hallgatók inkább valamilyen nemzetgazdasági ágnak tulajdonítják a levegőszennyezést, és nem a háztartásoknak. Pedig a tavalyi végzős tanító szakos hallgatók - a megkérdezettek - idén valószínűleg már a tanítói pályán vannak, tanítják a gyerekeket. Elképzelhetö, hogy környezetismeret-, esetleg természetismeretórát is tartanak, ahol hangsúlyozhatnák a háztartások szerepét a környezeti károk okozásában és az egyéni felelősségvállalás fontosságát, a környezettudatosságot. Vajon tényleg ezt teszik?

\section{Irodalom}

Bános K. (2012). A szálló por terheltség környezeti hatásai és csökkentésének gazdasági alternatívái. Doktori értekezés, Szent István Egyetem, Gödöllő

Boncz I. (2015). Kutatásmódszertani alapismeretek. Pécsi Tudományegyetem Egészségtudományi Kar. https://www.etk.pte.hu/protected/OktatasiAnyagok/ \%21Palyazati/sport/Kutatasmodszertan_e.pdf (2020.10.18.)

Csenger L. (2015). A környezeti nevelés elmélete és gyakorlata. Képzés és gyakorlat, 13(1-2.), 181-194.

https://doi.org/10.17165/TP.2015.1-2.11

Falus I. \& Ollé,J. (2000). Statisztikai módszerek pedagógusok számára. Okker Kiadó.

Field, A. (2017). Discovering Statistics Using IBM SPSS Statistics. SAGE Publications Ltd.

Fry, C. (2008). A klímaváltozás. Totem Plusz Könyvkiadó.

Központi Statisztikai Hivatal: Nemzetgazdasági ágak és háztartások üvegházhatású gáz-kibocsátása (1985-) http://www.ksh.hu/docs/hun/xstadat/xstadat_eves/i_ ua025d.html (2020.10.20.)

Központi Statisztikai Hivatal (2018). Környezeti helyzetkép, 2018. http://www.ksh. $\mathrm{hu} /$ docs/hun/xftp/idoszaki/pdf/kornyhelyzetkep18.pdf (2020.10.20.)

Kertész Á. (2001). A globális klímaváltozás természetföldrajza. Holnap Kiadó Kft. Mészáros E. (1993). Légkörtan. Veszprémi Egyetemi Kiadó. 
Pongrácz R. \& Bartholy J. (2010). A globális felmelegedés. A klímaváltozás tendenciái, területi különbségek, globális felmelegedés. In Törő K. (Ed.), Az éghajlatváltozás hatásai az emberi szervezetre (pp. 17-66.). Medicina Könyvkiadó Zrt.

Pongrácz R. (2012). Levegőszennyezés és éghajlatváltozás. In Szabó M. \& Angyal Zs. (Eds.), A környezetvédelem alapjai (pp. 154-217.). Typotex Kiadó.

Radnóti K. (2005). Az önálló ismeretszerzésre alapozott tanítás lehetősége a természettudományi nevelésben. Új Pedagógiai Szemle, 55(10), 61-67.

Zerényi, K. (2016). A Likert-skála adta lehetőségek és korlátok. Opus et Educatio, 3(4), 470-478.

https://doi.org/10.3311/ope.39 


\section{Kulman, K.}

\section{Opinion of students participating in elementary school teacher training on environmental problems in Hungary}

An important part of the work of primary school teachers is the environmental education and the sustainability education. In the framework of these, they prepare their students for the knowledge that can be used in everyday life, to understand environmental problems and to know their possible solutions. Environmental education involves developing a sense of individual responsibility and mastering a systems approach - for example, that certain economic, social and environmental phenomena are interlinked. I was curious about the opinion of the students majoring in research about which economic activities cause the most environmental problems in Hungary. I examined their views on the causes of carbon dioxide and greenhouse gases in the air. My research also covered the sources of their knowledge of the topic and whether industrial and / or mining environmental degradation could be worthwhile for an economic organization in terms of economic efficiency. The results of surveys have been analyzed by use of the SPSS statistical software.

Keywords: environmental problems, economic activity, teacher training

Kulman Katalin: https://orcid.org/0000-0003-2957-0253 